ISSN 0103-8478

\title{
Soil fungal and bacterial biomass determined by epifluorescence microscopy and mycorrhizal spore density in different sugarcane managements
}

\author{
Biomassa fúngica e bacteriana do solo determinada por microscopia de epifluorescência e \\ densidade de esporos micorrízicos em diferentes manejos de cana de açúcar
}

\author{
Adriana Pereira Aleixo $^{\mathrm{I}}$ Glaciela Kaschuk ${ }^{\mathrm{II}}$ Odair Alberton $^{\mathrm{I}}{ }^{*}$
}

\section{ABSTRACT}

Crop productivity and sustainability have often been related to soil organic matter and soil microbial biomass, especially because of their role in soil nutrient cycling. This study aimed at measuring fungal and bacterial biomass by epifluorescence microscopy and arbuscular mycorrhizal fungal $(A M F)$ spore density in sugarcane (Saccharum officinarum $L$.) fields under different managements. We collected soil samples of sugarcane fields managed with or without burning, with or without mechanized harvest, with or without application of vinasse and from nearby riparian native forest. The soil samples were collected at $10 \mathrm{~cm}$ depth and storage at $4^{\circ} \mathrm{C}$ until analysis. Fungal biomass varied from 25 to $37 \mu \mathrm{g} \mathrm{C} \mathrm{g}^{-1}$ dry soil and bacterial from 178 to $263 \mu \mathrm{g} \mathrm{C} g^{-1} d r y$ soil. The average fungal/bacterial ratio of fields was 0.14. The AMF spore density varied from 9 to 13 spores $g^{-1}$ dry soil. The different sugarcane managements did not affect $A M F$ spore density. In general, there were no significant changes of microbial biomass with crop management and riparian forest. However, the sum of fungal and bacterial biomass measured by

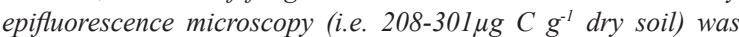
very close to values of total soil microbial biomass observed in other studies with traditional techniques (e.g. fumigationextraction). Therefore, determination of fungal/bacterial ratios by epifluorescence microscopy, associated with other parameters, appears to be a promising methodology to understand microbial functionality and nutrient cycling under different soil and crop managements.

Key words: Saccharum officinarum, soil microbial biomass, mycorrhiza.

\section{RESUMO}

A produtividade e sustentabilidade das culturas têm sido frequentemente relacionadas com a matéria orgânica e a biomassa microbiana do solo, especialmente devido ao seu papel na ciclagem de nutrientes do solo. Este trabalho teve como objetivo avaliar a biomassa de fungos e bactérias do solo por microscopia de epifluorescência e a densidade de esporos de fungos micorrízicos arbusculares (FMAs) em lavouras de cana de açúcar (Saccharum officinarum $L$.) sob diferentes manejos. Foram coletadas amostras de solo de lavouras manejadas com ou sem queima, com ou sem colheita mecanizada, com ou sem aplicação de vinhaça e de matas ciliares adjacentes. As amostras de solo foram coletadas a $10 \mathrm{~cm}$ de profundidade e mantidas a $4^{\circ} \mathrm{C}$ até o momento das análises. A biomassa fúngica variou de 25 a $37 \mu \mathrm{g} \mathrm{C} \mathrm{g}^{-1}$ de solo seco e a bacteriana, de 178 to $263 \mu \mathrm{g} \mathrm{C} g^{-1}$ de solo seco. A razão média entre a biomassa fúngica e bacteriana do solo nos diferentes manejos de canaviais foi de 0,14. A densidade de esporos de FMAs variou de 9 a 13 esporos $g^{-1}$ de solo seco. Os diferentes manejos da cana de açúcar não afetaram significativamente a densidade de esporos de FMAs. Em geral, não foram encontradas mudanças significativas na biomassa microbiana nos diferentes manejos de solo com cana de açúcar em comparação com a mata ciliar. Todavia, a soma das biomassas fúngicas e bacterianas (208 a $301 \mu \mathrm{g} \mathrm{C}^{-1}$ de solo seco) determinadas por microscopia de epifluorescência foram similares a resultados da biomassa total do solo encontrados em outros estudos com métodos tradicionais (e.g. fumigação-extração). Os resultados evidenciam que a determinação da razão fungo/ bactéria por microscopia de epifluorescência, associada a outros parâmetros, é uma metodologia promissora para compreender a funcionalidade microbiana e ciclagem de nutrientes sob diferentes manejos do solo.

Palavras-chave: Saccharum officinarum, biomassa microbiana do solo, micorrizas.

\section{INTRODUCTION}

Sugarcane (Saccharum officinarum L.) was introduced into Brazil in the 1500's, and since then, it has had a crucial role in Brazilian economy.

'Pós-graduação em Biotecnologia Aplicada à Agricultura, Universidade Paranaense (UNIPAR), Praça Mascarenhas de Moraes, Umuarama, PR, Brasil.

"UNIPAR, Praça Mascarenhas de Moraes, CP 4282, 87502-210, Umuarama, PR, Brasil. E-mail: odair@unipar.br. *Autor para correspondência. Received 10.22.12 Approved 10.30.13 Returned by the author 02.05.14 CR-2012-1025.R2 
In the season of $2011 / 2012$, the crop occupied 8.3 billons ha of the country area and raised about 20 billons dollars of revenue for the economy in the sugar and alcohol markets (MAPA, 2013). On one hand, expansion of sugarcane plantations should be constrained by land competition for food production or by legislation demands for forest preservation (CAMARGO et al., 2008, NOVO et al., 2010). On the other hand, the role of sugarcane may still increase by increasing its productivity and sustainability in the present agricultural areas.

Crop productivity and sustainability have often been related to soil organic matter (SOM) content due to the contribution of SOM on soil nutrient supply, water hold capacity, soil temperature, soil aggregation and soil microbial biomass (SMB) (BEARE, 1997; KASCHUK et al., 2010). The soil microorganism activity plays a crucial role in nutrient cycling and nutrient foraging by plant-microsymbionts (CONSTANZA et al., 1997; KASCHUK et al., 2010), and for that reason, may contribute to increase crop productivity.

Worldwide, and particularly in Brazil, SMB is usually determined by the fumigation-incubation (JENKINSON \& POWLSON, 1976) or by the fumigation-extraction (VANCE et al., 1987) methods that measure SMB indirectly from the fluxes of the $\mathrm{C}$ released in fumigated and non fumigated samples. Due to their reliability and robustness, both methods have been recommended for studies relating SBM to soil quality (KASCHUK et al., 2010). However, a drawback is that neither of them distinguishes the microbial communities, for example, the fungal and bacterial biomass.

It is already known that sugarcane management, which included application of vinasse (a by-product of sugarcane industry) to the fields and allowed straw to remain on the land after harvest of green sugarcane, leads to increases in SOM (CANELLAS et al., 2003; 2007). By knowing the benefits of SOM to the SBM and soil nutrient cycling (KASCHUK et al., 2010), this management could be recommended as sustainable practices for sugarcane production and improvement of soil quality; yet, there is a need of further understanding of the microbial role in these processes. The SBM is greatly affected by the amount of root exudates and plant metabolism. MARCHIORI-JUNIOR \& MELO (2000) reported that sugarcane accumulated more SMB than other crops and native forest, despite the fact that sugarcane management is based on high input of pesticides, which imposes a negative effect on soil microorganisms (KASCHUK et al., 2010).
They attributed the difference to the photosynthetic C4 metabolism of sugarcane plants in comparison with C3 metabolism of most crops and native forests (MARCHIORI-JUNIOR \& MELO, 2000; KASCHUK et al., 2010). Furthermore, greater amounts of SMB could be related to shifts in the microbial community composition, such as those observed in the fungal/bacterial ratios in pastures and crops submitted to different rates of nitrogen fertilization and different crop managements (BAILEY et al., 2002; DE VRIES et al., 2006). A better understanding of the soil microbial ecology would indicate better strategies of crop sustainability.

This study aimed at measuring fungal and bacterial biomass by epifluorescence microscopy and arbuscular mycorrhizal (AM) spore density in sugarcane (Saccharum officinarum L.) fields under different managements.

\section{MATERIAL AND METHODS}

Soil sampling

The study compared soil microbiological communities in six sugarcane fields with different crop management strategies (with or without burning, mechanization at harvest and vinasse application $\left( \pm 100 \mathrm{~m}^{3} \mathrm{ha}^{-1}\right)$, and native riparian forests in Novo Horizonte and Presidente Prudente, State of São Paulo-Brazil (Table 1). Soil samples were collected by Krion Agroscience Company during sugarcane cuttings in October and November, 2010, by digging $10 \mathrm{~cm}$ deep with a spade, cutting straight down a thin slice along one side of the hole. Samples were cleared out of debris, sieved through $4 \mathrm{~mm}$ mesh sieves and stored in plastic bags at $4^{\circ} \mathrm{C}$ until laboratory analyses, but no longer than a month. Each sample represented a mixture of ten subsamples collected randomly in each area. Soil characteristics are displayed in table 2.

\section{Arbuscular Mycorrhizal (AM) spore density \\ Spores were extracted from $10 \mathrm{~g}$ soil} subsamples by wet sieving, followed by suspension in water and centrifugation at $3000 \mathrm{rpm}$ for $3 \mathrm{~min}$, and in sucrose $50 \%$ at $2000 \mathrm{rpm}$ for $2 \mathrm{~min}$ (GERDEMANN $\&$ NILCOLSON, 1963). The spores were placed in Petri dishes and counted under a stereoscopic microscope (40X).

\section{Total soil fungi biomass}

Soil fungi biomass was extracted according to BLOEM \& VOS (2004). At first, a $6 \mathrm{~g}$ subsample was suspended in $190 \mathrm{~mL}$ distilled water and blended at high speed for $1 \mathrm{~min}$. An aliquot of $9 \mathrm{~mL}$ suspension 
Table 1 - Sugarcane field sites where soil samples were collected.

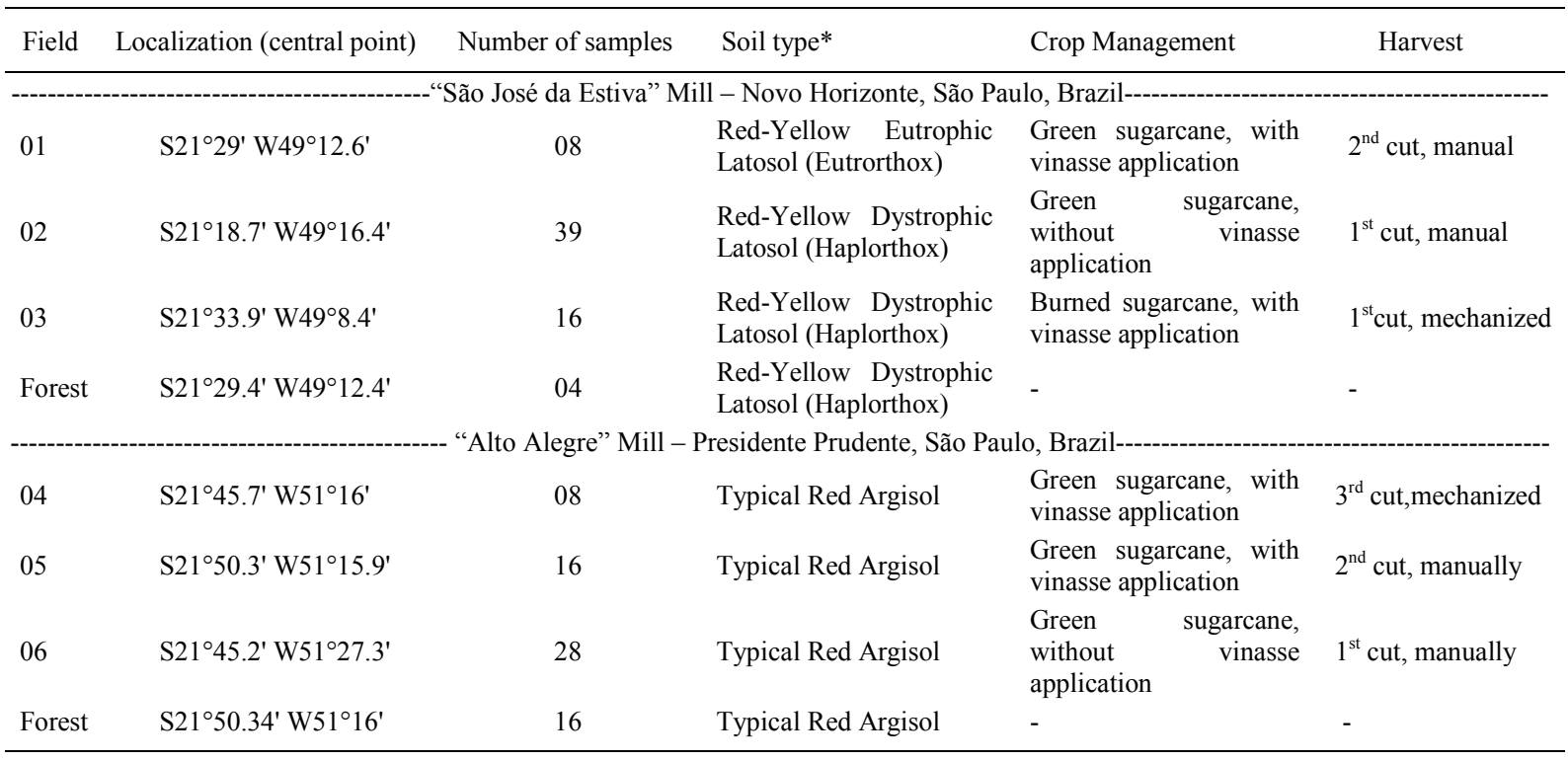

*All soils presented sandy texture.

was transferred to a $15 \mathrm{~mL}$ flask, gently mixed with $1 \mathrm{~mL}$ of formaldehyde $\left(37 \% \mathrm{w} \mathrm{v}^{-1}\right)$ and left rest for $2 \mathrm{~min}$. Twelve $\mathrm{mL}$ of the suspension was evenly spread on a microscope slide (previously disinfected with paper embedded in liquid soap and alcohol $96 \%$, dried at $50^{\circ} \mathrm{C}$ for $2 \mathrm{~h}$, and maintained on wet paper). Microscope slides were stained with $50 \mu \mathrm{L}$ of freshly prepared fluorescent brightener 28' solution (Sigma F3397: C40, H42, N12, O10, S2 and Na2 components; ethanol $50 \%, 1 \mathrm{mg} \mathrm{mL}^{-1}$ ) and placed in the dark at room temperature for $2 \mathrm{~h}$. The slides were submerged in distilled water three times for $20 \mathrm{~min}$ to remove dye excess, and, dried in the dark at room temperature. Finally, microscope slides were treated with a drop of immersion oil, covered with a slip and sealed with transparent nail polish. Hyphae were estimated under epifluorescence microscope (400X) by the gridline intersection method counting the presence and absence on 100 random fields. Length (m $\mathrm{g}^{-1} \mathrm{DW}$ ) was converted to fungi biomass as outlined by BLOEM \& VOS (2004). Microbial biomass was corrected to dry weight after determination of soil humidity in a second $10 \mathrm{~g}$ soil subsample.

Total soil bacterial biomass

Bacterial extraction and biomass determination was performed as described for hyphae, except that for staining bacteria it was used fluorescent protein dye 5-(4,6-dichlorotriazin-2IL) aminofluorescein or DTAF (solution: $2 \mathrm{mg}$ of DTAF dissolved in $10 \mathrm{~mL}$ of buffer solution $[0,05$ $\mathrm{M} \mathrm{Na}_{2} \mathrm{HPO}_{4}\left(7,8 \mathrm{~g} \mathrm{~L}^{-1}\right)$ and $0,85 \% \mathrm{NaCl}\left(8,5 \mathrm{~g} \mathrm{~L}^{-1}\right)$, adjusted to $\mathrm{pH} 9,0]$ ), instead of 28 'solution. Total bacteria biomass was also estimated according to BLOEM \& VOS (2004).

Statistical analysis

Data was subjected to one-way ANOVA using general linear model with mixed-effects and unbalanced design, considering each area as one treatment, and compared with the Duncan's test $(\mathrm{P} \leq 0.05)$, by using SPSS version 16.0 for Windows (SPSS Inc., Chicago, IL, USA). To comply with ANOVA assumptions, data was previously checked with the Levene's test.

\section{RESULTS AND DISCUSSION}

By using the epifluorescence microscopy method, we could estimated fungal biomass varying from 25 to $37 \mu \mathrm{g} \mathrm{C} \mathrm{g}^{-1}$ dry soil, and bacterial from 178 to $263 \mu \mathrm{g} \mathrm{C} \mathrm{g}^{-1}$ dry soil in sugarcane fields (Table 3). Both fungal and bacterial biomass were in the range of the values reported in the literature using the same method (BAILEY et al., 2002; DE VRIES et al., 2006; BUSSE et al., 2009). Furthermore, the 
Table 2 - Soil chemical characterization* of the sugarcane field sites where soil samples were collected. $\mathrm{Mean}^{\mathrm{a}}$ values of soil $\mathrm{pH}(\mathrm{CaCl})$, phosphorus (P), soil organic matter (O.M.), aluminum (Al), potential acidity $(\mathrm{H}+\mathrm{Al})$, calcium $(\mathrm{Ca})$, magnesium $(\mathrm{Mg})$, potassium $(\mathrm{K})$, bases sum (SB), cations exchangeable capacity (CEC), Iron (Fe), manganese (Mn), zinc (Zn) and bases saturation (BS). Explanation of fields is displayed in table 1.

\begin{tabular}{|c|c|c|c|c|c|c|c|c|c|c|c|c|c|c|c|}
\hline Field & $\mathrm{pH}$ & $\begin{array}{c}\mathrm{P} \\
\mathrm{mg} \mathrm{dm}^{-3}\end{array}$ & O.M. & $\begin{array}{r}\mathrm{S} \\
\mathrm{dm}^{-3}---\end{array}$ & $\mathrm{Al}^{3+}$ & $\mathrm{H}^{+}+\mathrm{Al}^{3+}$ & $\mathrm{Ca}^{2+}$ & $\begin{array}{c}\mathrm{Mg}^{2+} \\
\mathrm{mol}_{\mathrm{c}} \mathrm{dm}\end{array}$ & $\mathrm{K}^{+}$ & SB & CEC & $\mathrm{Fe}$ & $\begin{array}{r}\mathrm{Mn} \\
\mathrm{mg} \mathrm{dm^{-3 }}\end{array}$ & Zn & $\begin{array}{l}\text { BS } \\
\%\end{array}$ \\
\hline & & & & & של סט & & 1 & 811 & 110, & aulo & - & - & & 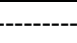 & \\
\hline 01 & 5.90 & 25.0 & 16.0 & 11.0 & 0.67 & 18.5 & 25.0 & 7.5 & 5,6 & 38.1 & 56.6 & 33 & 15.4 & 1.34 & 67 \\
\hline 02 & 5.64 & 40.8 & 13.0 & 5.8 & 0.68 & 17.7 & 32.0 & 8.1 & 2.5 & 42.6 & 60.3 & 22 & 24.7 & 1.18 & 50 \\
\hline 03 & 5.75 & 46.5 & 13.7 & 8.3 & 0.58 & 17.0 & 30.0 & 9.0 & 4.9 & 43.7 & 55.5 & 19 & 14.5 & 2.32 & 71 \\
\hline Forest & 4.00 & 13.0 & 22.0 & 8.0 & 4.82 & 53.0 & 13.0 & 6.0 & 3.0 & 22.0 & 75.2 & 95 & 55.1 & 1.28 & 29 \\
\hline & & & & 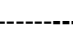 & Ito $\mathrm{A}$ & gre" Mill & - Presi & ite Pru & nte, Sã & aulo, $\mathrm{B}$ & zil---- & & & & \\
\hline 04 & 5.25 & 112.0 & 64.0 & 15.0 & 0.58 & 16.5 & 18.5 & 7.5 & 5.4 & 31.4 & 47.7 & ND & ND & ND & 65 \\
\hline 05 & 5.20 & 13.0 & 8.8 & 6.5 & 0.61 & 16.3 & 11.0 & 7.7 & 4.6 & 22.2 & 39.2 & ND & ND & ND & 57 \\
\hline 06 & 4.30 & 19.3 & 11.2 & 7.2 & 2.06 & 26.0 & 12.1 & 2.7 & 1.2 & 16.1 & 42.0 & ND & ND & ND & 39 \\
\hline Forest & 4.82 & 9.5 & 17.8 & 8.2 & 0.77 & 23.5 & 21.2 & 9.7 & 3.1 & 34.1 & 57.6 & ND & ND & ND & 56 \\
\hline
\end{tabular}

*Methods: P, K, Ca e Mg; extracted by resin; $\mathrm{Al}$ - extracted by $\mathrm{KCl} 1 \mathrm{~mol} \mathrm{~L}{ }^{-1}$; S-SO $\mathrm{S}_{4}-$ extr. $\mathrm{Ca}\left(\mathrm{H}_{2} \mathrm{PO}_{4}\right) 20.01$ mol L $\mathrm{L}^{-1}$; O.M. Dichromate/colorimetric; Fe, Mn e Zn - extr. DTPA - TEA pH 7,3. ND = Not determinated.

sum of fungal and bacterial biomass (208 to $301 \mu \mathrm{g}$ $\mathrm{C} \mathrm{g}^{-1}$ soil) (Table 3) was very close to total SMB determined elsewhere with the fumigation-extraction method in sugarcane fields (MENDONZA et al., 2000; PANKHURST et al., 2005. This corroborates the fact that fungi, bacteria and archea represent $75-98 \%$ of the total soil microbial biomass (KASCHUK et al., 2010).

Estimation of SMB from microscope observations is a more laborious procedure to estimate microbial biomass than indirect methods such as the usual fumigation-incubation (JENKINSON \& POWLSON, 1976) and fumigation-extraction (VANCE et al., 1987) methods, but it allows to distinguish and to quantify fungal from bacterial biomass independently. Molecular methods, like DGGE (Denaturating Gradient Gel Eletrophoresis) and 16S rRNA genes have been used to identify a diversity of fungi and bacteria in different sugarcane soil managements (DINI-ANDREOTE at al., 2010; PISA et al., 2011), but, these methods do not allow quantification of microbial biomass. This may be the first Brazilian study aiming to quantify soil fungal and bacterial biomass by epifluorescence from microscope observations in fields of sugarcane.

Crop management strongly influences soil microbial communities which, in turn, influence crop productivity and sustainability (KASCHUK et al., 2010). Previous studies on annual crops (soybean, maize, etc) demonstrated that crop management affects the $\mathrm{C} / \mathrm{N}$ relations in the SMB (PEREIRA et al.,
2007; HUNGRIA et al., 2009). These changes may be related to shifts in microbial composition, particularly the ones related to the abundance of fungal and bacterial biomass (BEARE, 1997; BAILEY et al., 2002). Indeed, there are studies demonstrating that increases in soil fungal biomass contributes to an increased immobilization of $\mathrm{N}$ due to protein storage in hyphae and spores (SIQUEIRA et al., 2010). In this study, sugarcane field without vinasse application (treatment 2; Table 3) lead to a significant decrease on bacterial biomass (below to $200 \mu \mathrm{g} \mathrm{g}^{-1}$ dry soil) in relation to the other treatments (Table 3 ). Nevertheless, this result does not sufficiently support the hypothesis that vinasse application could result in changes in the fungal/bacterial ratio, and for consequence, in the $\mathrm{C} / \mathrm{N}$ ratio of the SBM.

Spore density of AMF ranged from 9 to 13 spores $\mathrm{g}^{-1}$ dry soil (Table 3 ). These values are somewhat higher than usual values found in sugarcane fields (REIS et al., 1999; KELLY et al., 2001; DATTA \& KULKARNI, 2012), but spore densities in the magnitude of $10-16$ spores $\mathrm{dm}^{-3}$ have been observed in sugarcane rhizosphere in organicrich soils (REIS et al., 1999). Interestingly, there was no difference between native forest and sugarcane fields spore density value (Table 3). ZANGARO et al. (2000) found that trees in later forest succession stages are less dependent than pioneer tree species in initial phases of succession, meaning that forest in climax are not responsive to AMF root colonization. Similarly, KELLY et al. (2005) studying growth 
Table 3 - Fungal/Bacterial biomass and ratios and arbuscular mycorrhizal (AM) spores density in soil of sugarcane fields in Brazil. Explanation of fields is displayed in table 1.

\begin{tabular}{|c|c|c|c|c|c|}
\hline Field & $\begin{array}{l}\text { Fungal Biomass } \\
\text { ( } \mu \mathrm{g} \mathrm{C}^{-1} \text { soil) }\end{array}$ & $\begin{array}{l}\text { Baterial biomass } \\
\left(\mu \mathrm{g} \mathrm{C}^{-1} \text { soil }\right)\end{array}$ & $\begin{array}{l}\text { Fungal }+ \text { Bacterial } \\
\text { biomass }\end{array}$ & $\begin{array}{l}\text { Fungal/Bacterial } \\
\text { ratio }\end{array}$ & $\begin{array}{l}\text { AM spore density } \\
\left(\mathrm{g}^{-1} \text { soil }\right)\end{array}$ \\
\hline 01 & $24.75 \pm 3.0 \mathrm{a}$ & $234.04 \pm 29.5 \mathrm{ab}$ & $258.79 \pm 30.32 \mathrm{ab}$ & $0.115 \pm 0.019 \mathrm{a}$ & $11.36 \pm 2.1 \mathrm{a}$ \\
\hline 02 & $30.59 \pm 3.0 \mathrm{a}$ & $178.12 \pm 9.54 \mathrm{~b}$ & $208.71 \pm 11.11 \mathrm{~b}$ & $0.181 \pm 0.015 \mathrm{a}$ & $10.96 \pm 0.5 \mathrm{a}$ \\
\hline 03 & $37.35 \pm 3.5 \mathrm{a}$ & $263.47 \pm 18.2 \mathrm{a}$ & $300.82 \pm 16.91 \mathrm{a}$ & $0.163 \pm 0.027 \mathrm{a}$ & $13.07 \pm 4.1 \mathrm{a}$ \\
\hline Forest & $29.77 \pm 1.4 \mathrm{a}$ & $238.5 \pm 46.03 \mathrm{ab}$ & $268.28 \pm 46.34 \mathrm{ab}$ & $0.138 \pm 0.023 \mathrm{a}$ & $13.42 \pm 4.1 \mathrm{a}$ \\
\hline 04 & $32.46 \pm 5.2 \mathrm{a}$ & $212.18 \pm 29.8 \mathrm{a}$ & $244.67 \pm 28.52 \mathrm{a}$ & $0.199 \pm 0.05 \mathrm{a}$ & $9.68 \pm 1.8 \mathrm{a}$ \\
\hline 05 & $32.23 \pm 3.7 \mathrm{a}$ & $248.93 \pm 12.8 \mathrm{a}$ & $281.15 \pm 14.18 \mathrm{a}$ & $0.132 \pm 0.02 \mathrm{a}$ & $9.62 \pm 0.9 \mathrm{a}$ \\
\hline 06 & $31.55 \pm 2.9 \mathrm{a}$ & $226.86 \pm 13.8 \mathrm{a}$ & $258.41 \pm 14.89 \mathrm{a}$ & $0.149 \pm 0.01 \mathrm{a}$ & $11.7 \pm 0.8 \mathrm{a}$ \\
\hline Forest & $34.06 \pm 3.4 \mathrm{a}$ & $209.17 \pm 18.9 \mathrm{a}$ & $243.23 \pm 19.77 \mathrm{a}$ & $0.181 \pm 0.02 \mathrm{a}$ & $10.9 \pm 0.9 \mathrm{a}$ \\
\hline
\end{tabular}

*Means ( \pm standard error) followed by the same letter within in the column and same region do not differ significantly with Duncan's test at $\mathrm{P} \leq 0.05$.

responses of sugarcane to different mycorrhizal spore density concluded that sugarcane is poorly responsive to AMF, although it is unlikely that longterm sugarcane fields suffer a yield reduction because of mycorrhizal root colonization.

Another point is that we did not observe differences in spore densities in different sugarcane fields, even if there were slight differences in soil chemical characteristics (Table 2). Other studies carried out in sugarcane fields have found positive correlations between soil $\mathrm{pH}$ and AM spore density and root colonization (KELLY et al., 2001; DATTA \& KULKARNI, 2012; SIVAKUMAR, 2013) and negative correlations between electrical conductivity, nitrogen, and phosphorus contents in the soil (KELLY et al., 2001; DATTA \& KULKARNI, 2012).

Our study design included the most usual sugarcane managements and those were compared to nearby riparian native forests. It is already known that shifting from native forest into cropped systems decreases soil microbial biomass significantly (KASCHUK et al., 2010, 2011). However, we did not observe any significant difference in fungal and bacterial biomass between sugarcane fields and native forest soils, except for field number 2 from São José da Estiva Mill (Table 3). On one hand, sugarcane plantations may have stimulated SMB because of their C4 photosynthetic metabolism, which releases more exudates in the rhizosphere (MARCHIORI-JUNIOR \& MELO, 2000; KASCHUK et al., 2010); on the other hand, the frequent use of pesticides may have negatively affected SMB (KASCHUK et al., 2010) neutralizing the benefits of the root exudates. As a result, total SMB remained unchanged in relation to nearby forests.

\section{CONCLUSION}

The use of epifluorescence microscopy allows for measuring fungal and bacterial biomass distinguishingly in the same range of traditional methods of determination of SMB (e.g. fumigationextraction). Fungal and bacterial biomass determined by epifluorescence microscopy, associated with other parameters, such as the $\mathrm{C} / \mathrm{N}$ ratios, enzyme activity and soil biodiversity, and is a promising methodology to understand microbial functionality and nutrient cycling under different soil and crop managements.

\section{ACKNOWLEDGMENTS}

The authors thank FUNDAÇÃO ARAUCÁRIA (Project $\mathrm{N}^{\mathrm{o}}$ 18280) and the Universidade Paranaense for the financial support to do research. A.P. Aleixo thanks for a fellowship received from Universidade Paranaense for her Master's studies.

\section{REFERENCES}

BAILEY, V.L. et al. Fungal-to-bacterial ratios in soils investigated for enhanced $\mathrm{C}$ sequestration. Soil Biology and Biochemistry, v.34, p.997-1007, 2002. Available from: <http://www.sciencedirect. com/science/article/pii/S0038071702000330>. Accessed: Jun. 20, 2012. doi: 10.1016/S0038-0717(02)00033-0. 
BEARE, M.H. Fungal and bacterial pathways of organic matter decomposition and nitrogen mineralization in arable soils. In: BRUSSAARD, L.; FERRARA-CERRATO, R. (Eds.). Soil ecology in sustainable agricultural systems. Boca Ratón, FL: CRC/Lewis, 1997. p.37-40.

BLOEM, J.; VOS, A. Fluorescent staining of microbes for total direct counts. In: KOWALCHUK, G.A. et al. (Eds.) Molecular microbial ecology manual. 2.ed. Dordrecht, the Netherlands: Kluwer Academic Publishers, 2004. p.861-874.

BUSSE, M.D. et al. Soil carbon sequestration and changes in fungal and bacterial biomass following incorporation of forest residues. Soil Biology and Biochemistry, v.41, p.220-227, 2009. Available from: $<$ http://www. sciencedirect.com/science/article/pii/S0038071708003568>. Accessed: Set. 02, 2011. doi: 10.1016/j.soilbio.2008.10.012.

CAMARGO, A.M.M.P. et al. Dinâmica e tendência da expansão da cana-de-açúcar sobre as demais atividades agropecuárias, estado de São Paulo, 2001-2006. Informações Econômicas, v. 38, p.4766, 2008. Available from: <www.iea.sp.gov.br/out/bioenergia/ textos/ie-0308.pdf^. Accessed: May. 25, 2012.

CANELLAS, L.P. et al. Propriedades químicas de um Cambissolo cultivado com cana-de-açúcar, com preservação do palhiço e adição de vinhaça por longo tempo. Revista Brasileira de Ciência do Solo, v.27, p.935-944, 2003. Available from: <http://www.scielo. br/scielo.php?pid $=$ S0100-06832003000500018\&script $=$ sci abstract\&tlng=pt $>$. Accessed: Jun. 20, 2012 . doi: 10.1590/S010006832003000500018 .

CANELLAS, L.P. et al. Estoque e qualidade da matéria orgânica de um solo cultivado com cana-de-açúcar por longo tempo. Revista Brasileira de Ciência do Solo, v.31, p.331-340, 2007. Available from: <http://www.scielo.br/scielo.php?pid=S010006832007000200015\&script $=$ sci_arttext $>$. Accessed: Jul. 22, 2012. doi: 10.1590/S0100-06832007000200015.

CONSTANZA, R. et al. The value of the world's ecosystem services and natural capital. Nature, v.387, p.253-260, 1997. Available from: <http://www.nature.com/nature/journal/v387/ n6630/abs/387253a0.html>. Accessed: Jun. 20, 2012.

DATTA, P.; KULKARNI, M. Arbuscular mycorrhizal fungal diversity in sugarcane rhizosphere in relation with soil properties. Notulae Scientia Biologicae, v.4, n.1, p.66-74. 2012. Available from: $<$ http://notulaebiologicae.ro/index.php/nsb/article/view/6567>. Accessed: Set. 12, 2012.

DINI-ANDREOTE, F. et al. Bacterial soil community in a Brazilian sugarcane field. Plant and Soil, v.336, p.337-349. 2010. Available from: $<$ http://link.springer.com/article/10.1007\%2Fs11104-010-0486-z>. Accessed: Out. 18, 2011. doi: 10.1007/s11104-010-0486-Z.

DE VRIES, F.T. et al. Fungal/bacterial ratios in grassland with contrasting nitrogen management. Soil Biology and Biochemistry, v.38, p.2092-2103, 2006. Available from: <http:// www.sciencedirect.com/science/article/pii/S0038071706000903>. Accessed: Jun. 20, 2012. doi: 10.1016/j.soilbio.2006.01.008.

GERDEMANN, J.W.; NILCOLSON, T.H. Spores of mycorrhizal Endogone species extracted from soil by wet sieving and decanting. Transactions of the British Mycological Society, v.46, p.235-246, 1963. Available from: <http://www.sciencedirect.com/ science/article/pii/S0007153663800790>. Accessed: Ago. 11, 2010. doi: 10.1016/S0007-1536(63)80079-0.
HUNGRIA, M. et al. Soil microbial activity and crop sustainability in a long-term experiment with different soil tillage and crop rotation systems. Applied Soil Ecology, v.42, p.288-296, 2009. Available from: <http://www.sciencedirect.com/science/article/pii/ S0929139309001036>. Accessed: Jun. 20, 2012. doi: 10.1016/j. apsoil.2009.05.005

JENKINSON, D.S.; POWLSON, D.S. The effects of biocidal treatments on metabolism in soil - V. A method for measuring soil biomass. Soil Biology and Biochemistry, v.8, p.209-213, 1976. Available from: <http://www.sciencedirect.com/science/ article/pii/0038071776900055>. Accessed: Mar. 09, 2012. doi: 10.1016/0038-0717(76)90005-5.

KASCHUK, G. et al. Three decades of soil microbial biomass studies in Brazilian ecosystems: Lessons learned about soil quality and indications for improving sustainability. Soil Biology and Biochemistry, v.42, p.1-13, 2010. Available from: <http://www. sciencedirect.com/science/article/pii/S0038071709003095>. Accessed: Nov. 28, 2011. doi: 10.1016/j.soilbio.2009.08.020.

KASCHUK, G. et al. Quantifying effects of different agricultural land uses on soil microbial biomass and activity in Brazilian biomes: inferences to improve soil quality. Plant and Soil, v.338, p.467-481, 2011. Available from: <http://link.springer.com/ article/10.1007\%2Fs11104-010-0559-z>. Accessed: Nov. 28, 2011. doi: 10.1007/s11104-010-0559-z.

KELLY, R.M. et al. Responses of sugarcane, maize, and soybean to phosphorus and vesicular-arbuscular mycorrhizal fungi. Australian Journal of Agricultural Research, v.52, p.731743, 2001. Available from: < http://www.publish.csiro.au/paper/ AR00131.htm>. Accessed: Ago. 11, 2010. doi: 10.1071/AR00131.

KELLY, R.M. et al. Growth responses of sugarcane to mycorrhizal spore density and phosphours rate. Australian Journal of Agricultural Research, v.56, p.1405-1413, 2005. Available from: $<$ http://www.publish.csiro.au/paper/AR04185.htm>. Accessed: Jun. 12, 2011. doi: 10.1071/AR04185.

MAPA (MINISTERIO DA AGRICULTURA, PECUARIA E ABASTECIMENTO). Cana-de-açúcar. Available from: <http:// www.agricultura.gov.br/vegetal/culturas/cana-de-acucar $>$. Acessed: Ago. 26, 2013.

MARCHIORI-JUNIOR, M.; MELO, W.J. Changes in organic matter and microbial biomass of a natural forest under different management. Pesquisa Agropecuária Brasileira, v.35, p.11771182, 2000. Available from: <http://www.scielo.br/scielo. php? pid=S0100-204X2000000600014\&script $=$ sci_arttext $>$. Accessed: Jul. 21, 2012. doi: 10.1590/S0100-204X2000000600014.

MENDONZA, H.N.S. et al. Chemical and biological properties of a tableland soil cultivated with sugarcane with and without straw burning. Revista Brasileira de Ciência do Solo, v.24, p.201-207, 2000. Available from: <http://www.ia.ufrrj.br/lgcs/producao/ lucia/2000/1.pdf>. Accessed: Ago. 11, 2011.

NOVO, A. et al. Biofuel, dairy production and beef in Brazil: competing claims on land use in São Paulo state. Journal of Peasant Studies, v.37, p.769-792, 2010. Available from: <http:// www.ncbi.nlm.nih.gov/pubmed/21125724>. Accessed: Apr. 29, 2011. doi: $10.1080 / 03066150.2010 .512458$.

PANKHURST, C.E. et al. Effect of rotation breaks and organic matter amendments on the capacity of soils to develop biological 
suppression towards soil organisms associated with yield decline of sugarcane. Applied Soil Ecology, v.28, p.271-282, 2005 Available from: $<$ http://www.sciencedirect.com/science/article/pii/ S0929139304001040>. Accessed: Ago. 11, 2010. doi: 10.1016/j. apsoil.2004.07.010.

PEREIRA, A.A. et al. Variações qualitativas e quantitativas na microbiota do solo e na fixação biológica do nitrogênio sob diferentes manejos com soja. Revista Brasileira de Ciência do Solo, v.31, p.1397-1412, 2007. Available from: <http://www.scielo.br/scielo. php?pid=S0100-06832007000600017\&script $=$ sci abstract\&tlng=ES $>$. Accessed: Jun. 11, 2012. doi: 10.1590/S0100-06832007000600017.

PISA, G. et al. Diversity of $16 \mathrm{~S}$ rRNA genes from bacteria of sugarcane rhizosphere soil. Brazilian Journal of Medical and Biological Research, v.44, p.1215-1221, 2011. Available from: $<$ http://www.scielo.br/scielo.php?script=sci_arttext\&pid=S0100879X2011001200004>. Accessed: Ago. 01, 2012. doi: 10.1590/ S0100-879X2011007500148.

REIS, V.M. et al. Ocorrência de micorrizas arbusculares e da bactéria diazotrófica Acetobacter diazotrophicus em cana-de-açúcar. Pesquisa Agropecuária Brasileira, v.34, p.1933-1941, 1999. Available from: <http://www.scielo.br/scielo.php?pid=S0100-
204X1999001000021\&script=sci_arttext $>$. Accessed: Ago. 11, 2012. doi: 10.1590/S0100-204X1999001000021.

SIQUEIRA, J.O. et al. Micorrizas: 30 anos de pesquisa no Brasil. Lavras: UFLA, 2010. 716p.

SIVAKUMAR N. Effect of edaphic factors and seasonal variation on spore density and root colonization of arbuscular mycorrhizal fungi in sugarcane fields. Annals of Microbiololgy, v.63, p.151160,2013 . Available from: <http://link.springer.com/article/10 .1007\%2Fs13213-012-0455-2>. Accessed: Jun. 19, 2012. doi: $10.1007 / \mathrm{s} 13213-012-0455-2$.

VANCE, E.D. et al. An extraction method for measuring soil microbial biomass C. Soil Biology and Biochemistry, v.19, p.703-707, 1987. Available from: <http://www.sciencedirect.com/ science/article/pii/0038071787900526>. Accessed: May. 18, 2010. doi: 10.1016/0038-0717(87)90052-6.

ZANGARO, W. et al. Mycorrhizal dependency, inoculum potential and habitat preference of native woody species in South Brazil. Journal of Tropical Ecology, v.16, p.603-622, 2000. Available from: <http://journals.cambridge.org/action/displayAbstract?from Page $=$ online\&aid $=60895>$. Accessed: Ago. 11, 2011. 